\title{
Information System and Transparency Free School Program
}

\author{
Meilia Rosani ${ }^{1}$, Netti Karnati ${ }^{2}$, Elliana Sari ${ }^{3}$ \\ \{meiliarosani18@gmail.com, neti.karnati@unj.ac.id, briont-ramadhan@yahoo.com\} \\ Universitas Negeri Jakarta, Indonesia ${ }^{123}$
}

\begin{abstract}
This study describes the information system and transparency of a free school program using a qualitative approach with a case study method. The techniques and procedures for data collection included interviews and direct observation. The validity of the data was done with credibility, flexibility, dependability, and commitment. Data analysis consisted of testing, categorizing, tabulating, or combining based on the focus of the research. From data analysis, the school information system was free in MUBA Regency and used a computerized system in determining the number of recipients of funds through dapodik data, socialization through a website, and distribution of FSP reserves via bank transfer. In addition, the transparency of the financial accountability of FSP funds in accordance with the technical guidelines was carried out properly. This is because it was supported by supervision carried out by the District Management and the District Inspectorate Teams as well as Non-Governmental Organizations.
\end{abstract}

Keywords: Free Schools, Information Systems, Transparency

\section{Introduction}

The nature of education has two very basic things. The first one relates to access to education services and is influenced by the availability and affordability. The second one relates to quality and is strongly influenced by three things; the availability and quality of teachers, curriculum, and facilities ${ }^{1}$. Free schools program aims to provide costless education services while maintaining quality. However, its implementation certainly experience many obstacles and challenges. Researcher CW Wachhia stated that the free school program has its own constraints, including the stigma of parents worried about the quality of their education, discipline and effectiveness of teaching as well as learning provided the free school program is implemented ${ }^{2}$. This is, of course, very much related to the quality and characteristics of the school in relation to commitment to success, flexibility and responsibility, vision, teaching, and discipline climate associated to free school programs ${ }^{3}$.

The implementation of the Free School Program (FSP) in the field of education has to consider various related aspects such as school management information systems that are able to bring changes in the scope of leadership, decision making, workload, responsibilities, making long-term plans, forming methods for future education, and teacher performance ${ }^{4}$. Good management in the 
education sector is key to the running of FSP. Speaking of education management, the main thing for consideration is management. Colquitt, Lepine and Wesson asserted that management is an integral and fundamental part in supporting the success of an organization ${ }^{5}$, an assertion reinforced by Tony and Bell who established that managements are concepts where leadership is an integral part. Management itself means the efforts to achieve certain goals through activities of others ${ }^{6}$. In management, an organization means creating a structure with parts integrated to have influence on one another and jointly do the work in order to achieve predetermined goals. In other words, organizing is the determination of what needs to be done, how, and who will do it ${ }^{7}$.

The management concept accommodating the implementation of a free school program with various obstacles it faces is an information system that utilizes technological advancements. The transparency related to the implementation of free school programs can be more accountable, especially in the management of free school funds right on target. However, in the management of the HR roles, the presence of teachers is absolutely needed in the free school program. Indeed, teachers, as the main indicators of the success of this program, must be capable of improving their knowledge, develop skills and possess inter-intra-charm characters. Important still, they should have a good religious perspective, reflecting them directly in their daily lives ${ }^{8}$. Also, internal factors which consist of physical and psychological and external aspects including family and school related issues such as teaching methods, curriculum, discipline, and supporting infrastructure in education are equally imperative ${ }^{9}$.

In addition, in the administration of education a leader plays a very significant role. For instance, a leader must avoid social tyranny and be authoritarian, display openness to an input or criticism, and have a good sense of humanity ${ }^{10}$. At the beginning of the $21^{\text {st }}$ century, leadership in the education sector attracted a lot of attention. This was due to the growing belief that leadership quality had an impact on output quality, teachers and students ${ }^{11}$. In addition, with the development of digital technology and devices in the modern era, a leader in the field of education is required to accept and use management information systems in with regard to efficient administrative services ${ }^{12}$.

In Indonesia, precisely in the Province of South Sumatra, the Musi Banyuasin District, Free School Program (FSP) contributes to the improvement on the quality of education. This is depicted by the Gross Enrollment Rate (GER) of elementary school or Sekolah Dasar (SD) in 2014 from 118.61 to 118.71 in 2015. There was also an upsurge in junior high school level from 99.58 in 2014 to 99.65 in 2015 and high school or vocational high school level from 99.50 in 2014 to 99.70 in 2015. The increase in education performance was accompanied by a decline in dropout rates. In elementary school in 2014 it amounted to 0.04 compared to 0.02 in 2015. The junior high school level was originally 0.14 in 2014 but 0.04 in 2015. From the aforementioned facts, the description of the information system and transparency of the free school program in improving the quality of education is an interesting and very significant aspect to explain, especially FSP in Musi Banyuasin District (MUBA). 


\section{Research Methodology}

The study used a qualitative approach with a case study method. A qualitative research always attempt to give meaning to one's understanding (subjective connotation) from the subject under study. The researchers must try to capture, understand and expand information in certain categories and patterns, and must be able to analyze the social context occurring in the subject under study ${ }^{13}$. Case studies can be interpreted as analytical and descriptive researches in details regarding a program organized by individuals, organizations, institutions or communities in certain environmental contexts ${ }^{14}$. According to Merriam, Yin and Stake, "a case study is a detailed examination of one setting, a single subject, a sole depository document, or a particular event" 15 . The sources of data in this study were interviews with related parties, that is, the Musi Banyuasin District Education Office (MUBA) consisting of the Management Teams, Principals, School Treasurers, students, teachers, parents, and school committees. The techniques and procedures for collecting data in this study included interview, observation and documentation studies (https://osf.io/preprints/inarxiv/t6gfs).

\section{Research Results and Discussion}

\subsection{Free School Program Information System}

Based on field observations, interviews and supporting documents, the free school program in Musi Banyuasin Regency began in 2002. The imitative started with the budget planning process by collecting data on students in public schools. But along with its development, it is estimated that between 2010 and 2017, the recipients of FSP funds at each level of education were based on dapodik data for each school using a computerized technology system. This would ensure that data relating to student in the education units can be accurately known, the basis for determining the amount of funds to be issued. In addition, the dissemination of information related to FSP was carried out through a website that can be accessed 24 hours. After the dapodik data were obtained, they were incorporated into the Dinas Dikbud budget plan based on the amount been set into the current year Budget Activity Plan or Rencana Kegiatan Anggaran (RKA). The RKA was submitted to the Regional Development Planning Agency (Bappeda) as material in the regional development plan, the Musyawarah Rencana Pembangunan (Musrenbang) deliberation process and subsequently discussed by the District Regional Budgeting Team, the Tim AnggaranPerangkat Daerah (TAPD), chaired by the Regional Secretary. It consisted of the Regional Financial and Asset Management Agency, commonly referred to as the Badan Pengelolaan Keuangan dan Aset Daerah (BPKAD), the Regional Development Planning Agency or Badan Perencanaan Pembangunan Daerah (BAPPEDA), Regional Revenue Service or Dinas Pendapatan Daerah (DISPENDA), and Inspectorate. After obtaining approval from TAPD, the Free School Program RKA was submitted to the DPRD to be discussed for approval. If the Muba DPRD approves the proposed program and budget, the SKPD Budget Executing Document (DPA) is issued by the Muba District Education and Culture Office. From the DPA, payment requests could be made in accordance with the schedule and needs. Payment or distribution of free school funds could be made if the institutions have 
qualifying for the same had been identified. The funds could be issued by the Head of the MUBA District Education and Culture Office.

The accuracy of dapodik data could be credibly accounted for because the computerized system of each school had been integrated directly into the Central Government, in the Ministry of Education and Culture of the Republic of Indonesia through a software program. Computerized technology owned by each school in Muba Regency is one of the main factors for the success of the implementation of FSP which has been running for approximately 15 years. The speed in getting access to information and the accuracy of data from the database related to the number of students who obtained FSP funds provided convenience and smooth implementation of the program. In addition, through rapid technological advancements, the pattern of distribution of funds was done via the Bank and transferred to school accounts, which of course were safer, flexible, and accountable and could avoid unwanted things. The effectiveness of time and Human Resources is another positive impact felt in the implementation of the program related to the utilization of technological advances in education management. Although, in its development the allocation of FSP funds received by the school is used for the financing component; a) honorarium of vice principal, homeroom teacher $(15 \%)$, b) honorarium for honorary / GTT teachers, non-permanent employees / PTT (60\%), c) honorarium for extracurricular activities (15\%), and d) consumption of coaching meetings in school (10\%).

\subsection{Free School Transparency}

From the interviews and documentation studies, the person in charge of free school funds is appointed with a Decree of the Head of the Office regarding the appointment of the Acting Technical Implementation Officer (PPTK) of the District Education and Culture Office's District Budget. PPTK, which manages the funds, is incorporated into a special team responsible for carrying out its duties in distributing free school funds to all schools consisting of; a) Head of Service as Budget User, b) Head of Planning as a Budget User Proxy, c) Head of Division in charge of planning as Activity Control Officer (PPTK), d) Regular Treasurer of Education and Culture Office of MUBA Regency as Treasurer of Free School Program, e ) Planning and Education Staff of the Education and Culture Office as Assistant Treasurer, and f) Staff in charge of schooling and division of tasks adjusted to the functions based on the points in the Decree signed.

At the school level, a free school fund responsible work team was formed and served as a supervisory body in the management of the finances that went into school accounts / foundations. The organizational structure of the management team at the school level consisted of the person in charge, that is, the Principal and 2 other members, the School Treasurer and Parents of Students. The duties and responsibilities of the management team at the school include: a) completing, sending and updating the basic education data in full into a system provided by the Ministry of Education and Culture (Dapodik), b) making RKAS based on all sources of the school, c ) verifying the amount of funds received with existing student data, d) managing funds in a responsible and transparent manner, e) announce the amount of money received and controlled by the institution and plan for the use funds in the form of RKAS, f) making a report on the realization of the use of quarterly finances as a mechanism of accountability for the use of funds and stored for monitoring and audit purposes, g) preparing financial reports submitted to the district education SKPD, and $h$ ) conduct an orderly accounting for Free School Program funds. 
The establishment of a school management team and a Technical Implementation Officer (PPTK) is an appropriate step to avoid misappropriation of FSP funds carried out in the form of supervision. Supervision is a function of administration or management useful in controlling an activity and efforts to achieve organizational goals ${ }^{16}$.In another perspective, supervision can be defined as an activity meant to direct individuals to attain organizational goals ${ }^{17}$. For this reason, supervision and control in its implementation needs to be done correctly, transparently and have good accountability. The forms of supervision carried out based on the results of FSP's research in MUBA District have been carried out through internal supervision by the District Education and Culture Office and school supervisory elements confirmed through the Principal's Decree while external supervision is carried out by the Muba District Inspectorate on an ongoing basis.

The results of interviews with school treasurers showed reporting is carried out regularly and in every quarter. At the end of the year, the school is also required to make an annual report and submit it to the MUBA District Education and Culture Office. Besides, accounting in the general cash book containing financial records of both income and expenses is carried out form of bookkeeping, namely: General Cash Book, Cash Book, Bank Ledgers, and Tax Book. Supervision related to the management and use of FSP funds in MUBA Regency, is also carried out by all people in MUBA District through community organizations (NGOs) that actively participate and oversee the use and management of funds. With this, it is clear that transparency in the management and implementation of FSP in Muba Regency has been done well. Muba can be applied in other areas so that all children can get proper education without difficulties brought about by funding problems. In the future, the internet network will be well connected, and therefore the use of technology in making FSP fund accountability reports can be done. This can involve the application of E-Money so that transparency in managing the funds can be credibly accounted for.

\section{Conclusion}

The information systems utilizing technological advances such as internet networks and computer systems have a significant influence on the implementation of Free School Programs. The speed in obtaining access to information and the accuracy of data from the database related to the number of students eligible for FSP funds offered convenience and smooth implementation of the program in Musi Banyuasin Regency. The effectiveness of time and Human Resources is another positive impact felt in the implementation of FSP in relation to the use of technological advances in education management. Furthermore, utilizing technological advances in education management and minimizing errors in the implementation of FSP is possible because the information system used facilitates implementation of FSP transparent, especially in the fund management. Transparency in this regard is a form of accountability well monitored by non-governmental organizations, in addition to the supervision carried out by the relevant Office and Inspectorate within the government of the Musi Banyuasin Regency.

\section{References}


[1] A. Hamid, Aida Hanim dan Azlin Norhaini Mansor, Wong Kim Eng, Mohamad Sattra Rasul, Mohd. Izham Mohd Hamzah, "Effective Clasroom Management." Internasional Journal Education Studies, Vol 5, No. 5, pp. 35, July 31 (2012)

[2] Bell, Les dan Tony Bush. The Principles and Practice of Educational Management. California: Paul Chapman Publising (2002)

[3] Biklen, Sari Knoop, Robert C dan Bogdan. Qualitatif Research for Education; an Intoroduction to Theories and Methods. New York: Pearson (2007)

[4] Bush, Tony. "Educational Leardership and Management Theory, Policy, and Practice." South African Journal of Education.Vol 27(3) pp. 391 (2007)

[5] Coulter, Mary dan Stephen P. Robbins. Manajemen Jilid I Edisi ke-10. Jakarta: Erlangga (2009)

[6] Creswell, John W. Reseach Design: Qualitative and Quantitative Approaches. California: California Publicationn (1994)

[7] Demir, Kamile. "Free School Management Information System in Primary School." The Turkey online Journal Tecnology-TOJET. Vol. 5 Issue 2 Article 6, pp. 32, April (2006)

[8] Hussain, Zina Hamody. "School Administration and Role in Promoting Intellectual Security among Students." Internasional Journal of Science and Research (IJSR), Vol. 6, Issue 12, PP. 159, December (2017)

[9] Lakip. Dinas Pendidikan Provinsi Sumatera Selatan (2015)

[10] Mbugua, nd Z.K. dan C.W. Wachira, E. Mweda, G.M. Mutha. "Impact of Free Primary Education on Management of Primary Schools In Embu West District in Kenya." Internasional Journal of Business.Humanities and Technologi. Vol 1, No. 2, pp. 157, September (2011)

[11] Muhktar, Mukhneri. Pengawasan Pendidikan. BPJM Press: Universitas Negeri Jakarta (2013)

[12] Nadeak, Bernadetha. "Learning Achievement of UKI Students Eastern Indonesia." International Journal of Science and Risearch (IJSR). Vol. 4 Issue 11, pp. 621, November (2015) [13] Orodho, Jhon Aluko dan Jackline Tabitha Nzoka. "School Management and Students' Academic Performance: How Effective are Strategies being Employed by School Managers in Secondary Schools in Embu Nort Distric, Embu Contry, Kenya." Internasional Journal of Humanities and Social Science. Vol. 4, No. 9 pp. 87, Juli (2014)

[14] Rahma, Sidiq Auli dan Teti Ratnawulan. "Management Profile of Guidance and Coundseling in Junir High School." Internasional Journal of Social Sciences. Vol 3 Issue 3.pp. 334-350, 5 December (2017)

[15] Sudjana, Djuju. EvaluasiPendidikanLuarSekolah. Bandung: Remaja Rosdakarya (2008)

[16] Wesson, Colquitt, dan LePine. Organizational Behavior, Improving Pwerformance and Commitment in the Workplace. New York: McGraw Hill (2009) 